\title{
Kemandirian Peradilan Agama Dalam Perspektif Undang-Undang Peradilan Agama
}

\author{
Oleh: Sumadi Matrais \\ Hakim Pengadilan Agama Yogyakarta \\ e- mail:
}

\begin{abstract}
It is widely understood that Islamic court in Indonesia is not an independent body of court of justice or judiciary system. This is caused mainly by the lack of legal support.

So, it may be concluded that the dependency of religious court in Indonesia is as a sensible consequence of the flaws in the existing legal framework
\end{abstract}

Keywords: Peradilan Agama, Undang-Undang Peradilan Agama

\section{Pendahuluan}

Berbicara mengenai sejarah Peradilan Agama di Indonesia, siapa pun harus mengakui secara jujur bahwa keberadaannya di negara ini sudah cukup memakan waktu yang panjang, sepanjang keberadaan agama Islam itu sendiri. Dikatakan demikian, karena memang Islam merupakan agama hukum dalam arti kata yang sebenarnya. Maksudnya ialah, selain agama Islam mengandung kaidah-kaidah yang mengatur hubungan manusia dengan Tuhan, Allah, Yang Maha Esa yang sepenuhnya dapat dilaksanakan oleh pemeluk agama Islam secara pribadi, juga mengandung kaidah-kaidah yang mengatur hubungan manusia dengan manusia lain, dan dalam kehidupan bermasyarakat yang memerlukan bantuan penyelenggara negara untuk bisa melaksanakannya dengan sempurna. Dengan demikian, berarti bahwa Islam dan Hukum Islam selalu beriringan dan tidak bisa dipisah-pisahkan. ${ }^{1}$ Karena itu, pertumbuhan Islam selalu

${ }^{1}$ Daud Ali, “Undang-Undang Peradilan Agama”, Panji Masyarakat, (ed.), No. 634 tanggal 1-10 Januari, 1990, Jakarta, hlm. 71. 
sekaligus diikuti oleh pertumbuhan hukum Islamnya itu sendiri. ${ }^{2}$ Jabatan Hakim di dalam Islam lebih merupakan kelengkapan daripada pelaksanaan syariat Islam. Sedangkan peradilannya merupakan kewajiban kolektif (fardhu kifayah), yakni sesuatu yang dapat ada dan harus dilaksanakan dalam keadaan bagaimanapun. ${ }^{3}$

Di negara Indonesia yang berdasarkan Pancasila dan UndangUndang Dasar 1945, keadilan, kebenaran, dan kepastian hukum dalam konteks sistem penyelenggaraan hukum merupakan hal pokok yang sangat penting dalam mewujudkan suasana kehidupan yang aman, tenteram, dan tertib seperti yang diamanatkan Garis-Garis Besar Haluan Negara (GBHN). ${ }^{4}$ Salah satu lembaga untuk menegakkan hukum adalah badan-badan peradilan sebagaimana yang dimaksud dalam UndangUndang No. 4 Tahun 2004, yang masing-masing mempunyai lingkup kewenangan mengadili perkara atau sengketa di bidang tertentu dan salah satunya adalah Peradilan Agama.

Secara umum, Undang-Undang No. 7 Tahun 1989 jo Undang-Undang No. 3 tahun 2006 telah membawa perubahan besar dan kemajuan pesat bagi keberadaan Peradilan Agama. Dengan Undang-Undang tersebut antara lain diharapkan akan tercipta unifikasi hukum di lingkungan Peradilan Agama dalam kerangka sistem dan tata hukum nasional.

Dari sudut pandangan historis, Lembaga Peradilan Agama apabila didasarkan pada Stbl 1882 Nomor 152 tergolong tua di Republik Indonesia, meskipun demikian implementasinya masih menghadapi berbagai persoalan. Hal ini antara lain menyangkut masalah kemandirian Peradilan Agama dalam melaksanakan tugas dan wewenangnya berdasarkan Undang-Undang Nomor 7 Tahun 1989 jo undang-Undang Nomor 3 tahun 2006 tentang Perubahan atas Undang-Undang Nomor 7 Tahun 1989 tentang Peradilan Agama.

Dalam mengimplementasikan kewenangannya, ternyata Peradilan Agama mengalami gangguan (disturbance), antara lain berupa:

1. Pengaruh dari adanya pluralisme sistem hukum di Indonesia, yaitu sistem hukum Adat yang mengatur hukum waris Adat, sistem hukum Islam yang mengatur hukum waris Islam, sistem hukum Barat (BW)

\footnotetext{
${ }^{2}$ Victor Tanja, Forum RUUPA, Editor, No. 48/Th II, Jakarta, 5 Agustus 1989.

${ }^{3}$ Zaini Ahmad Noeh dan Abdul Basit Adnan, Sejarah Singkat Pengadilan Agama Islam di Indonesia, Bina Ilmu: Surabaya, 1983, hlm. 29.

${ }^{4}$ Lihat, "Penjelasan Atas Undang-Undang Republik Indonesia Nomor 7 Tahun 1989 tentang Peradilan Agama".
} 
yang mengatur hukum waris (KHUH Perdata). Dalam pembagian warisan, para ahli waris yang tidak beragama Islam, terutama yang wanita akan menggunakan hak opsi (pilihan hukum) menurut hukumnya sendiri, kemandirian Peradilan Agama terganggu.

2. Pasal 50 Undang-Undang Nomor 7 Tahun 1989 tentang Peradilan Agama jo Pasal 50 ayat (1) Undang-Undang Nomor 3 Tahun 2006 tentang Perubahan atas Undang-Undang Nomor 7 Tahun 1989 tentang Peradilan Agama, mengatur tentang sengketa milik, menyatakan:

Dalam hal terjadi sengketa hak milik atau keperdataan lain dalam perkara-perkara sebagaimana yang dimaksud dalam Pasal 49, maka khusus mengenai obyek yang menjadi sengketa tersebut harus diputus lebih dahulu oleh Pengadilan dalam lingkungan Peradilan Umum. Pasal 49 adalah kewenangan mutlak (absolut) Peradilan Agama yang meliputi perkara: perkawinan, waris, hibah, wakaf, zakat, infak, shodaqoh, dan ekonomi syari'ah. Gangguan yang timbul dari pasal tersebut adalah:

1. Menjadi kendala bagi Peradilan Agama dalam melaksanakan kewenangan yang dimiliki.

2. Menimbulkan kerancuan acara dan proses penyelesaian perkara.

3. Penyelesaian perkara jadi berbelit-belit dengan waktu yang lama.

4. Menimbulkan biaya yang tinggi, menyengsarakan pencari keadilan, dan menghabiskan tenaga.

5. Tidak sejalan dengan asas-asas pokok peradilan yang cepat, ringan, dan biaya yang murah.

Berdasarkan kajian terhadap Undang-Undang Nomor 7 Tahun 1989 tentang Peradilan Agama jo Undang-Undang No. 3 tahun 2006 tentang Perubahan atas Undang-Undang No. 7 Tahun 1989 tentang Peradilan Agama, ternyata masih tersisa pertanyaan bagaimana upaya untuk mengembalikan kemandirian Peradilan Agama dalam melaksanakan tugas dan wewenangnya.

\section{Peradilan Agama dalam Perspektif Historis, Filosofis, Yuridis, dan Sosiologis}

Secara historis, filosofis, yuridis, dan sosiologis bisa dijelaskan sebagai berikut:

\section{Historis}

\section{a. Masa Awal Pemelukan dan Kerajaan-kerajaan Islam}


Peradilan Agama di Indonesia telah ada sejak Islam ada di bumi Indonesia pada abad ke-7 atau ke-8 Masehi, ${ }^{5}$ sesuai dengan tingkat dan bentuknya sebagaimana ditentukan hukum Islam.

Tentu saja, pada mulanya agama Islam di Indonesia dianut oleh orangorang secara sendiri-sendiri, yaitu belum terbentuk sebagai suatu masyarakat Islam yang teratur dan berkembang sebagaimana sekarang. Dalam keadaan Islam semacam itu, Peradilan Agama masih berbentuk Tahkim, yakni bentuk penyerahan kepada seorang Muhakkam untuk menjatuhkan suatu hukum atas suatu persengketaan. Pengangkatannya dilakukan langsung oleh pihak-pihak yang bersengketa. Sementara itu, dalam masyarakat yang telah teratur namun belum sampai mempunyai pemerintahan, maka pembentukan peradilan dan pengangkatan jabatan hakimnya bisa dilakukan dengan cara musyawarah dan pemilihan serta Bai'at Ahlul Halli wal Aqdi, yaitu pengangkatan atas seseorang yang dipercaya oleh majelis atau kumpulan orang-orang terkemuka di dalam masyarakat, seperti kepala suku atau kepala adat dan lain-lain.

Dalam perkembangan selanjutnya, Islam sebagai sebuah agama dan hukum semakin mengakar dan dominan mewarnai hampir seluruh kehidupan bangsa ini. Kenyataan ini sudah mulai berlaku sejak Islam ditetapkan sebagai agama resmi di Kerajaan Demak sekitar abad lima belas. ${ }^{6}$ Kemudian para sultan di Indonesia, di antaranya sultan di Aceh, Pagaruyung, Bonjol, Pajang, Banjar, dan Pasai, memberlakukan Islam sebagai agama resmi dan hukum negara. ${ }^{7}$ Akhirnya, puncak dominasi Islam berlaku pada zaman Kerajaan Mataram di tangan Sultan Agung sekitar $1750 \mathrm{M}$ yang memberlakukan hukum Islam secara total, baik dalam perkara pidana maupun perdata. ${ }^{8}$ Jadi di Indonesia hukum Islam pernah diterima dan dilaksanakan seluruhnya oleh masyarakat Islam. ${ }^{9}$ Pada masa itu berlaku teori Receptio in Complexu yaitu bahwa hukum Islam diterima (diserap) secara menyeluruh oleh umat Islam. Teori ini dipelopori oleh Carl Frederik Winter, Salomon Keyzen, dan LWC van den Berg, yang

\footnotetext{
${ }^{5}$ Hamka, Sejarah Umat Islam, Jilid III, Jakarta: Bulan Bintang, 1981, hlm. 35.

${ }^{6}$ Baca "Sejarah Peradilan Agama", Serial Media Dakwah, ASA, Jakarta, Agustus, 1989.

${ }^{7}$ Idrus Ramulyo M, Beberapa Masalah tentang Hukum Acara Perdata Peradilan Agama dan Hukum Perkawinan Islam, Jakarta: Ind-Hell Co, 1985, hlm. 8.

${ }^{8}$ ASA, op.cit.

${ }^{9}$ Ahmad Rofiq, Hukum Islam di Indonesia, Ctk 4, Jakarta: PT. Raja Grafindo Persada, 2000, hlm. 12.
} 
menyatakan bahwa hukum itu mengikuti agama yang dianut oleh seseorang. ${ }^{10}$ Belakangan teori ini didukung oleh teori Receptio Exit yang dipelopori oleh Hazairin yang mengatakan bahwa hukum adat dapat berlaku apabila tidak bertentangan dengan hukum Islam. ${ }^{11}$

Akan tetapi, Snouck Hurgronje kemudian membuat teori yang disebut teori Receptio yaitu bahwa hukum yang berlaku bagi orang Islam adalah hukum adat mereka masing-masing. Hukum Islam bisa berlaku bila sudah diresapi oleh hukum adat. Jadi, hukum adatlah yang menentukan adatidaknya hukum Islam. ${ }^{12}$ Teori ini dikemukakan oleh C. Snouck Hurgronje dan C. van Vollenhoven.

Dalam keadaan semacam itu, dalam rangka mendukung politik "memecah-belah" (devide et impera), Pemerintah Kolonial Belanda mengeluarkan Stbl. 1882 Nomor 152 yaitu dengan memisahkan pelaksanaan hukum Islam di Jawa dan Madura dengan daerah luar Jawa dan Madura yang masih diserahkan kepada peraturan-peraturan Adat dan Swapraja. Sejak itu, bentuk peradilannya tidak lagi berbentuk Tahkim seperti pada awal-awal pemelukan Islam, melainkan sudah meningkat ke bentuk peradilan (qadla). Maka, mulai dikenal beberapa istilah: Sidang Jum'at, Rapat Ulama, Rapat Agama, Mahkamah Syara', dan Soerambi, dan istilah-istilah itulah yang kita kenal sebagai Peradilan Agama sekarang ini. Pengangkatan pengambil putusan atau hakimnya pun sudah tidak lagi berdasarkan penunjukkan langsung oleh para pihak yang bersengketa dan pemilihan serta bai'at Ahlul Hilli wal Aqdhi, melainkan sudah melalui pemberian kekuasaan (tauliyah) oleh pemerintah dan penguasa (Ulil Amri). Maka, mulailah dikenal adanya peraturan-peraturan adat dan Swapraja sebagai dasar keberadaannya. ${ }^{13}$

Istilah-istilah lain yang kita kenal dengan Kanjeng Penghulu, Penghulu, Tuanku Mupti, maupun Tuanku Kadi, disamping raja-raja dan bupati dahulu, merupakan penjelmaan dari watak dan kepribadian ketatanegaraan dari pelaksanaan syari'at Islam di Indonesia. ${ }^{14}$

\section{b. Masa Pemerintahan Kolonial}

${ }^{10}$ Munawir Sjadzali, Landasan Pemikiran Politik Hukum Islam dalam Rangka Menentukan Peradilan Agama, dalam Tjun Suryaman (ed), tanpa nama, hlm. 43-45.

${ }^{11}$ Sayuti Thalib, Receptio a Contrario, Jakarta: Pura Aksara, 1982, hlm. 65.

${ }^{12}$ Munawir Sjadzali, op.cit., hlm. 45.

${ }^{13}$ Marulah Pardede, Eksistensi dan Kedudukan Hukum Peradilan Agama dalam Tata Hukum Indonesia, Jakarta: Angkatan Bersenjata, 24 Agustus 1989. 
Ketika memasuki Indonesia melalui VOC, yakni sebuah wadah dagang yang telah mengarahkan sasarannya untuk menjajah Nusantara, Pemerintah Kolonial Belanda tidak dapat menyepelekan keberadaan Hukum Islam yang telah berurat berakar dilaksanakan oleh masyarakat Islam Indonesia. VOC, yang akhirnya semakin kokoh mencengkeram bahkan kemudian menjajah Nusantara ini, tidak mampu menekan dan membendung pelaksanaan hukum Islam yang telah menjadi keyakinan hidup. Upaya penghapusan hukum Islam sama sekali, yang dilakukan terus-menerus, hanya mampu dilakukan dalam bidang hukum pidana. ${ }^{15}$ Pemerintah Kolonial mengadakan aturan pemisahan antara peradilan keduniawian (wereldlijke rechtspraak) seperti dilakukan pengadilan Gubernamen dan Pengadilan Agama.

Untuk bidang hukum perdata, karena telah dijalankan lama dan cukup mapan, tetap dibiarkan hidup, berjalan, dan di tangani sendiri oleh Peradilan Agama, sedangkan kepala Pendeta (maksudnya Ulama, karena Ulama dikira sama dengan Pendeta) dibiarkan untuk memutus perkara-perkara tertentu dalam bidang perkawinan dan kewarisan. ${ }^{16}$

Campur tangan Pemerintah Kolonial terhadap Peradilan Agama (pelaksanaan hukum perdata Islam) baru dimulai pada tahun $1820 \mathrm{M}$ sebagaimana tertuang pada Stbl. 1820 No. 24 Pasal 13 yang diperjelas oleh Stbl. 1835 No. 58 isinya antara lain: “Apabila terjadi sengketa antara orang-orang Jawa satu sama lain mengenai soal-soal perkawinan, pembagian harta dan sengketa-sengketa yang sejenis yang harus diputus menurut hukum Islam, maka para "pendeta" memberi putusan, tetapi gugatan untuk mendapat pembayaran yang timbul dari keputusan para "pendeta" itu harus dijatuhkan kepada pengadilan-pengadilan biasa."

Atas usul L.W.C. van den Berg (1845-1927) berdasarkan teori receptio in complexu, yaitu paham yang mengatakan bahwa hukum bagi orang Indonesia mengikuti agamanya, ${ }^{17}$ Pemerintah Kolonial Belanda akhirnya memberikan aturan secara formal dalam perundang-undangan yang lebih konkrit atas pelaksanaan hukum Islam, yaitu Stbl. 1882 No. 152 tentang

${ }^{14}$ Departemen Agama RI, “Laporan Bagian Proyek Penelitian Yurisprudensi Peradilan Agama", Proyek Peningkatan Penelitian/Survey Keagamaan, Jakarta, 1971/ 1972, hlm. 71.

${ }^{15}$ ASA, op.cit.

${ }^{16}$ Mahadi, "Peranan Pengadilan Agama di Indonesia", Kertas Kerja, Laporan Hasil Simposium Sejarah Peradilan Agama, Bagian Proyek Pembinaan Administrasi Hukum dan Peradilan Agama, Jakarta, 1982/1983, hlm. 68. 
pembentukan Pengadilan Agama di Jawa dan Madura dengan nama Priesterraden (Pengadilan Pendeta, satu sebutan yang keliru tentunya). Sedangkan untuk daerah luar Jawa dan Madura masih diserahkan kepada peraturan-peraturan Adat maupun Swapraja. Hal ini karena Jawa dan Madura dianggap sebagai pilot proyek untuk menguasai wilayah Indonesia seluruhnya.

Meskipun Pengadilan Agama telah diatur secara formal sebagai pengadilan negara, sebagaimana Pengadilan Gubernamen, tetapi dalam kenyataan, keduanya tidak didudukkan secara sama. Untuk Pengadilan Gubernamen disediakan anggaran secukupnya dan para pegawainya pun digaji oleh negara, sedangkan Pengadilan Agama tidak demikian, kecuali ketuanya-ini pun dalam kedudukan ketua sebagai Penghulu Landraad. Biaya-biaya yang diperlukan untuk kebutuhan administrasi harus dicukupi dari biaya perkara yang didapatnya. Akibatnya, jarang orangorang Alim (yang menguasai ilmu agama) mau menjadi pegawai Pengadilan Agama, sehingga sering terjadi para pegawainya diangkat dari pengurus-pengurus masjid yang kurang menguasai ilmu agama. ${ }^{18}$

Berbeda dengan L.W.C. van den Berg, penganut dan pencetus teori receptio in complexu, adalah C. Snouck Hurgronje (1857-1936). Ia adalah salah seorang ahli Hukum Adat dan mencetuskan teori baru yang sangat bertentangan dengan teori L.W.C. van den Berg. Teori C. Snouck Hurgronje itu dikenal dengan teori receptie, yakni teori yang mempunyai jalan pikiran bahwa:

“Sebenarnya yang berlaku di Indonesia adalah Hukum Adat asli. Ke dalam Hukum Adat ini memang telah masuk pengaruh Hukum Islam. Pengaruh Hukum Islam itu baru mempunyai kekuatan kalau dikehendaki dan diterima oleh Hukum Adat dan dengan demikian lahirlah dia sebagai Hukum Adat bukan sebagai Hukum Islam."19

Berdasarkan teori ini, C. Snouck Hurgronje, yang menduduki jabatan sebagai Penasehat Pemerintah Hindia Belanda tentang soal-soal Islam dan anak negeri, menganggap bahwa keluarnya Stbl. 1882 No. 152 merupakan kesalahan yang patut disesalkan. Sebab Peradilan Agama ini seharusnya dibiarkan terus berjalan tanpa campur tangan Pemerintah, sehingga keputusan-keputusannya tidak perlu memperoleh kekuatan Undang-

\footnotetext{
${ }^{17}$ Sayuti Thalib, op.cit., hlm. 5.

${ }^{18}$ Zaini Ahmad Noeh dan Abdul Basit, op.cit., hlm. 33.

${ }^{19}$ Sayuti Thalib, op.cit., hlm. 13.
} 
Undang. ${ }^{20}$

Dengan desakan dan pengaruh dari C. Snouck Hurgronje dalam kedudukannya itu, maka secara sistematis, halus, dan berangsur-angsur hukum agama yang sudah berlaku bagi orang Islam mulai diubah dan dipersempit ruang geraknya dalam kehidupan masyarakat, sehingga menimbulkan banyak reaksi dan kekecewaan dalam benak masyarakat Islam.

Kenyataan di atas ditandai, misalnya, dengan adanya perubahan ketentuan Pasal 134 IS 1925 (yang bunyinya sama dengan ketentuan Pasal 78 RR 1855, RR 1907 dan RR 1919 dulu), di mana ayat yang ke-2 berbunyi:

"Kalau terjadi perselisihan perdata antara sesama penduduk inlander atau penduduk yang dipersamakan dengan mereka diputuslah oleh kepala agama atau kepala adat mereka menurut Undang-Undang agamanya atau adat aslinya,..." diubah menjadi:

Dalam hal terjadi perkara perdata antara sesama orang Islam akan diselesaikan oleh hukum agama Islam, apabila hukum adat mereka menghendaki dan sejauh tidak ditentukan lain dengan suatu ordonansi.

Perubahan ini terjadi pada tahun 1929, berdasarkan Stbl. 1929 No. 221. Dengan demikian, berarti bahwa Hukum Islam telah dicabut dari lingkungan tata hukum Hindia Belanda. Akibatnya, melalui Stbl. 1931 No. 53 terjadi pengurangan wewenang bagi Pengadilan Agama yang hanya tinggal mengenai persengketaan dalam bidang nikah, talak, rujuk, perceraian dan hal-hal lain yang berhubungan dengan itu seperti mahar dan nafkah istri. Sedangkan bidang hadlanah (penguasaan dan pemeliharaan anak), waris, wakaf dan lain-lain dicabut dan selanjutnya diserahkan kepada Landraad.

Meskipun Stbl. 1931 No. 53 tidak sempat diberlakukan, namun akhirnya Pemerintah Kolonial Belanda mengeluarkan ordonansi baru berupa Stbl. 1937 No. 116 yang diberlakukan mulai tanggal 1 April 1937 tentang perubahan dan penambahan atas Stbl. 1882 No. 152. Namun demikian, intinya, isi Stbl. tersebut adalah untuk mengurangi wewenang Pengadilan Agama seperti Stbl. 1931 No. 53 di atas. Hal ini terlihat jelas pada bunyi Pasal 2a ayat (1):

Pengadilan Agama hanya semata-mata berwenang untuk memeriksa dan memutuskan perselisihan-perselisihan hukum antara suami-istri yang beragama Islam, begitu pula perkara-perkara lain tentang nikah, talak,

${ }^{20}$ Zaini Ahmad Noeh dan Abdul Basit, op.cit., hlm. 34. 
dan rujuk serta soal-soal perceraian lain yang harus diputuskan oleh hakim agama, menyatakan perceraian dan menetapkan bahwa syarat-syarat talak sudah berlaku... . Kecuali dalam perkara mahar (mas kawin) dan pembayaran nafkah wajib bagi suami kepada istri yang sepenuhnya menjadi wewenang Pengadilan Agama.

Kemudian, Pemerintah Kolonial Belanda mengeluarkan Stbl. 1937 No. 610 tentang pembentukan Mahkamah Islam Tinggi yang berkedudukan di Jakarta sebagai Pengadilan Agama Tingkat Banding untuk Jawa dan Madura yang mulai diberlakukan tanggal 1 Januari 1938. Kekuasaannya adalah untuk :

1. Memeriksa dan mengadili aneka perkara yang menjadi wewenang Pengadilan Agama yang dimintakan banding.

2. Memberikan saran-saran atau pertimbangan-pertimbangan masalah agama Islam kepada pemerintah apabila diminta. ${ }^{21}$

Pada akhir tahun itu juga, tepatnya tanggal 21 Desember 1937 Pemerintah Kolonial Belanda mengeluarkan ordonansi lagi: Stbl. 1937 No. 368 dan 369 tentang pengaturan dan pembentukan Kadigerecht (Karapatan Kadi) di sebagian daerah Kalimantan Selatan (kecuali daerah Pulau Laut, Tanah Bumbu dan Hulu Sungai), dan het Upperkadirecht (Karapatan Kadi Besar) di Banjarmasin yang diberlakukan mulai tanggal 1 Januari 1938.

Sampai akhir masa kekuasaannya (setelah dikalahkan Jepang), Pemerintah Kolonial Belanda tak sempat mengatur Pengadilan Agama untuk pulau Jawa, Madura, dan sebagian Kalimantan Selatan, sehingga keberadaannya untuk daerah tersebut tetap didasarkan pada peraturanperaturan Adat maupun Swapraja.

Selama kekuasaan Jepang di Indonesia (1942-1945), keadaan Peradilan Agama masih sebagaimana keadaannya di masa Pemerintah Kolonial Belanda, dalam arti tidak ada perubahan-perubahan kecuali penyesuaian nama menjadi Sooryoo Hoin untuk Pengadilan Agama / Kerapatan Kadi dan Kaikyoo Kooto Hoin untuk Mahkamah Islam Tinggi/Kerapatan Kadi Besar. $^{22}$

Keadaan seperti ini bukan berarti Jepang menyetujui susunan badan peradilan, termasuk Peradilan Agama, yang sudah diatur oleh Pemerintah Kolonial Belanda, tetapi semata-mata karena kesibukannya dalam

\footnotetext{
${ }^{21} \mathrm{Ibid}, \mathrm{hlm} .38$.

${ }^{22} \mathrm{Ibid}, \mathrm{hlm} .21$.
} 
menghadapi peperangan di mana-mana selama pemerintahannya di Indonesia.

Di masa Pemerintahan Kolonial Belanda maupun Pemerintahan Jepang, Pengadilan Agama termasuk urusan Departemen Kehakiman. Sebelum ada Pengadilan Agama tingkat banding (Mahkamah Islam Tinggi tahun 1937), kalau ada ketidakpuasan atas putusan Pengadilan Agama, maka satu-satunya jalan adalah dengan memohon peninjauan kembali atas putusan tersebut kepada Gubernur Jenderal. ${ }^{23}$

\section{c. Masa Sesudah Kemerdekaan dan Pemerintahan Orde Lama}

Beberapa saat setelah dicapai kemerdekaan, ibukota Republik Indonesia, Jakarta, diduduki tentara sekutu. Dalam keadaan demikian, Pemerintah Republik Indonesia diungsikan dari Jakarta ke Yogyakarta. Sehubungan dengan itu, berdasarkan Keputusan Menteri Kehakiman No. T2, Kedudukan Mahkamah Islam Tinggi dipindahkan pula dari Jakarta ke Surakarta.

Dengan kemerdekaan yang dapat diraih oleh bangsa Indonesia, Pemerintah Republik Indonesia mulai mengadakan perubahan dalam hampir segala bidang, termasuk Peradilan Agama. Setelah Pemerintah RI mendirikan Departemen Agama berdasarkan penetapannya tanggal 3 Januari 1946 No. 1/SD, urusan Peradilan Agama yang semula berada di bawah Departemen Kehakiman, berdasarkan penetapannya tanggal 25 Maret 1946 dipindahkan ke Departemen Agama.

Namun seiring dengan perombakan susunan peradilan kolonial, Pemerintah Republik Indonesia pada 1948 mengeluarkan satu UndangUndang tentang Susunan dan Kekuasaan Badan-badan Kehakiman dan Kejaksaan dengan Undang-Undang No. 19 Tahun 1948.

Ternyata undang-undang ini jelas menghendaki dihapuskannya Peradilan Agama sebagai lembaga peradilan yang berdiri sendiri. ${ }^{24}$ Selanjutnya, untuk menangani perkara yang selama ini ditangani oleh Peradilan Agama, ditampung oleh Pengadilan Negeri secara istimewa dengan bentuk penanganan perkaranya diketuai seorang hakim yang beragama Islam dan didampingi oleh dua hakim ahli agama Islam. ${ }^{25}$

Untuk daerah-daerah yang secara de facto dikuasai Pemerintah RI,

\footnotetext{
${ }^{23}$ Laporan Bagian Proyek Penelitian Yurisprudensi Peradilan Agama, hlm. 29.

${ }^{24}$ Baca Taufiq Hamami, "Ikhtisar Sejarah Peradilan Agama di Indonesia" (ed), Mimbar Hukum, No. 59 Th. XIV, 2003, hlm. 21.
} 
pelaksanaan Peradilan Agama yang berdasarkan ketentuan Pasal II Aturan Peralihan Undang-Undang Dasar 1945 masih didasarkan pada Stl. 1882 No. 152 jo Stbl. 1937 No. 1116 dan 610 untuk Jawa dan Madura.

Bagi daerah-daerah yang dikuasai tentara Sekutu dan Belanda, di beberapa tempat didirikan Peradilan Agama dengan nama Penghulu Gerechten sebagai pengganti Priesterraden. Sedang untuk Peradilan Agama tingkat banding, didirikan beberapa Majelis Ulama. Ini untuk mengimbangi Mahkamah Islam Tinggi yang dipindahkan ke Surakarta pada $1946 .^{26}$

Setelah penyerahan kedudukan Pemerintah Kolonial Belanda kepada Pemerintah Republik Indonesia pada 27 Desember 1949, maka peraturanperaturan tentang Penghulu Gerechten tersebut, seperti di Javaasche courant No. 32 Tahun 1946, No. 25 dan 39 Tahun 1949, Keputusan Recomba Jawa Barat No. Rechto praak WJ 2972 Tahun 1948, dan yang lainnya, dianggap tidak berlaku (terhapus) berdasarkan Peraturan Pemerintah Pengganti Undang-Undang No. 1 Tahun 1950 (Perpu No. 1 Tahun 1950), yang diganti dengan Undang-Undang No. 8 Tahun 1950. Selanjutnya Stbl. 1882 No. 152 jo Stbl. 1937 No. 116 dan 610 dianggap tidak berlaku.

Pada 1951, melalui Penetapan Menteri Agama No. 1 Tahun 1951, diadakan penataan nasib para pegawai Peradilan Agama dengan pengangkatan mereka menjadi pegawai negara. Sehingga, mereka yang pada zaman penjajahan tidak mendapat gaji sekarang mendapatkannya secara tetap dari negara. ${ }^{27}$ Selain itu, pengangkatan atas jabatan Ketua Pengadilan Agama beserta para pegawainya, juga pemberhentiannya, menjadi wewenang Menteri Agama, bukan lagi wewenang Bupati atau Residen seperti pada zaman penjajahan.

Selanjutnya, dalam usaha mencapai satu kesatuan dalam bidang peradilan secara menyeluruh, Pemerintah RI mengeluarkan UndangUndang Darurat No. 1 Tahun 1951 tentang Tindakan Sementara untuk Menyelenggarakan Kesatuan Susunan Kekuasaan dan Acara pada Pengadilan Sipil. Berdasarkan undang-undang ini, Pengadilan Adat dan Swapraja dihapuskan. Akibatnya, peradilan-peradilan di luar Pulau Jawa dan Madura serta sebagian daerah Kalimantan Selatan, merasa kurang mempunyai landasan hukum yang kuat. Oleh karena itu, jalan keluarnya

\footnotetext{
${ }^{25}$ Zaini Ahmad Noeh dan Abdul Basit, op.cit., hlm. 54-55.

${ }^{26}$ Laporan Bagian Proyek Penelitian Yurisprudensi Peradilan Agama, hlm. 33.

27 Ibid.
} 
adalah bahwa, berdasarkan Pasal 1 ayat (2) dan (4) Undang-Undang tersebut, Pengadilan Agama yang berada dalam lingkungan Peradilan Adat dan Swapraja, jika menjadi bagian tersendiri dari badan peradilan tersebut (Adat dan Swapraja), tak akan dihapus, dan sebagai kelanjutannya akan diatur dengan Peraturan Pemerintah.

Untuk memenuhi Pasal 1 ayat (2) dan (4) Undang-Undang tersebut, yakni dalam rangka memberi landasan hukum yang kuat bagi Peradilan Agama di daerah-daerah luar pulau Jawa dan Madura serta sebagian Kalimantan Selatan, maka diajukan satu rancangan Peraturan Pemerintah tentang pembentukan Pengadilan Agama atau Mahkamah Syari'ah untuk daerah Aceh, yang segera mendapatkan pengesahan dari Dewan Menteri, dan akhirnya keluarlah Peraturan Pemerintah No. 22 Tahun 1957.

Peraturan Pemerintah No. 22 Tahun 1957 tersebut ternyata tidak bisa memberikan penyelesaian secara integral bagi daerah-daerah yang lain. Akhirnya, peraturan pemerintah itu dicabut dan digantikan oleh Peraturan Pemerintah No. 45 Tahun 1957, tentang pembentukan Pengadilan Agama (Mahkamah Syari'ah di daerah luar Jawa dan Madura serta sebagian Kalimantan Selatan) yang mulai berlaku pada tanggal 9 Oktober 1957.

Berdasarkan Peraturan Pemerintah PP No. 22 Tahun 1957 tersebut, Menteri Agama mengeluarkan penetapannya No. 58 Tahun 1957 tentang Pembentukan 54 Pengadilan Agama/Mahkamah Syari'ah Propinsi untuk daerah Sumatera. Lalu, disusul dengan Pembentukan Pengadilan Agama/ Mahkamah Syari'ah di Indonesia Bagian Timur dan Pengadilan Agama/ Mahkamah Syari'ah Propinsi di Banjarmasin dan Ujung Pandang (Makasar).

\section{d. Masa Pemerintahan Orde Baru}

Di masa awal Pemerintahan Orde Baru, tindakan pertama yang dilakukan dalam rangka penataan pelaksanaan Kekuasaan Kehakiman secara murni berdasar kehendak Undang-Undang Dasar 1945, sesuai ketentuan Ketetapan MPRS No. XIX/MPRS/1966 jo No. XXXIX /MPRS/ 1968 adalah bahwa pemerintah bersama DPR-GR mengadakan peninjauan atas Undang-Undang No. 19 Tahun 1964 dengan UndangUndang No. 6 Tahun 1969 yang menghendaki adanya Undang-Undang tentang Ketentuan-ketentuan Pokok Kekuasaan Kehakiman yang baru (penggantinya). Sebagai realisasinya, pada tanggal 17 Desember 1970 disahkan dan diundangkan Undang-Undang No. 14 Tahun 1970. 
Berdasarkan Undang-Undang No. 14 Tahun 1970 ini, keberadaan Peradilan Agama makin kokoh sebagai salah satu lembaga pelaksana Kekuasaan Kehakiman di Negara Republik Indonesia. Bahkan sesuai dengan ketentuan Pasal 10 ayat (1), kedudukannya setaraf dengan peradilan-peradilan lainnya, seperti Peradilan Umum, Peradilan Militer, dan Peradilan Tata Usaha Negara.

Kekokohannya makin menonjol setelah disahkannya UndangUndang No. 1 Tahun 1974 tentang Perkawinan pada tanggal 2 Januari 1974 dan Peraturan Pemerintah No. 9 Tahun 1975 tentang Pelaksanaan Undang-Undang No. 1 Tahun 1974 tentang Perkawinan, yang berlaku secara efektif pada tanggal 1 Oktober 1975. Kemudian disusul dengan diundangkannya Peraturan Pemerintah No. 28 Tahun 1977 tentang Wakaf, beserta pelaksanaannya.

Dengan dikeluarkannya peraturan perundang-undangan tersebut, selain memperkokoh keberadaan Peradilan Agama, juga memperluas beban tugasnya. Tidak dapat dipungkiri pula bahwa, pengesahan peraturan-perundang-undangan tersebut menggugah dan membangkitkan kembali peran dan fungsi badan Peradilan Agama, sehingga perkara yang masuk naik setiap tahun. Sebagai indikasi, pada 1974 sebanyak 28.650, pada 1975 naik 48.000, dan pada 1976 sebanyak 142.069 perkara. $^{28}$

Seiring dengan kian meningkatnya pengetahuan dan kesadaran hukum masyarakat, kasasi atau perkara-perkara yang telah diputus oleh Pengadilan Agama mulai diajukan ke Mahkamah Agung, sementara hukum acara yang harus dimiliki tentang kasasi sesuai kehendak Pasal 12 Undang-Undang No. 14 Tahun 1970 belum ada. Untuk mengatasi masalah ini, maka Mahkamah Agung pada tanggal 26 November 1977 mengeluarkan Peraturan No. 1 Tahun 1977 tentang Jalan Pengadilan dalam Pemeriksaan Kasasi untuk Perkara Perdata dan Perkara Pidana oleh Pengadilan Agama dan Pengadilan Militer, disertai Surat Edaran (SE) No. MA/Pemb/0921/1977.29

Dengan demikian, baik Mahkamah Islam Tinggi, Kerapatan Kadi Besar maupun Pengadilan Agama Mahkamah Syari'ah Provinsi, yang selama ini selain berfungsi sebagai atau merupakan Pengadilan Tingkat

\footnotetext{
${ }^{28}$ Departemen Agama, "Yurisprudensi Badan Peradilan Agama", Ditbinbapera Islam, Jakarta, 1977, hlm. 1.

${ }^{29}$ Taufiq Hamami, op.cit., hlm. 23.
} 
Banding juga berfungsi sebagai atau merupakan Pengadilan Tertinggi di lingkungan Peradilan Agama, terhapus sudah.

Untuk sementara, sampai dengan dimilikinya Undang-Undang tentang Susunan Kekuasaan dan Acara Peradilan Agama yang integral sesuai kehendak Pasal 12 Undang-Undang No. 14 Tahun 1970, maka demi keseragaman warna Peradilan Agama yang selama ini berbeda-beda akibat dari keberadaan peraturan-perundang-undangan yang mengaturnya (Stbl. 1882 No. 152, Stbl. 1937 No. 116 dan 610, Stbl 1937 No. 638 dan 639, dan PP No. 45 Tahun 1957), Keputusan Menteri Agama tanggal 28 Januari 1980 No. 6 Tahun 1980 jelah menyatakan bahwa Pengadilan Tingkat Banding adalah Pengadilan Tinggi Agama (PTA). Dengan demikian, nama Mahkamah Islam Tinggi, Kerapatan Kadi dan Kerapatan Kadi Besar, serta Mahkamah Syari'ah Provinsi sudah tidak digunakan lagi.

Sesuai dengan kenyataan itu, untuk dapat memantapkan dan memegang teguh tugas serta fungsi Pengadilan Agama sebagai salah satu lingkungan peradilan di jajaran Kekuasaan Kehakiman di negara ini, pada 27 Maret 1982 Presiden Republik Indonesia mengangkat seorang Ketua Muda Mahkamah Agung Urusan Lingkungan Peradilan Agama. Dengan demikian, jelas berarti bahwa tugas pembinaan teknis yustisial atas Pengadilan Agama yang selama ini dilakukan langsung oleh Departemen Agama, telah menjadi wewenang penuh Mahkamah Agung sesuai kehendak Undang-Undang No. 14 Tahun 1970 tentang Ketentuanketentuan Pokok Kekuasaan Kehakiman itu sendiri.

Pada 1982, Pemerintah melalui Keputusan Menteri Agama No. 95 Tahun 1982 membentuk pula beberapa cabang Pengadilan Tinggi Agama dan Pengadilan Agama untuk Indonesia Tengah dan Timur, seperti Nusa Tenggara Timur, Timor Timur, Sulawesi, Maluku, dan Irian Jaya. Selanjutnya, Pengadilan Tinggi Agama (Mahkamah Islam Tinggi) Surakarta dipindah kembali ke Jakarta dan untuk Pengadilan Tingkat Banding di Provinsi Jawa Tengah, maka didirikanlah Cabang Pengadilan Tinggi Agama di Semarang.

Pada akhirnya, sebagai puncak dari kekokohan dan kemapanan badan Peradilan Agama sebagai suatu bagian dari Peradilan Negara di Indonesia ditandai dengan disahkannya Undang-Undang No. 7 Tahun 1989 tentang Peradilan Agama pada tanggal 27 Desember 1989, mengenai Susunan Kekuasaan dan Acara Peradilan Agama. Dengan disahkannya UndangUndang Peradilan Agama ini, terpenuhilah sudah kehendak dari Pasal 
10 ayat (1) Undang-Undang No. 14 Tahun 1970 tentang kesetarafan dan kesejajaran Peradilan Agama dengan Peradilan Negara yang lain. Ini karena Peradilan Agama sudah tidak lagi harus menggantungkan kepada Pengadilan Negeri dalam hal melaksanakan putusannya (eksekusi), dan tidak lagi memerlukan pengukuhan atas putusan-putusan Pengadilan Agama yang telah punya kekuatan hukum tetap sebelum dijalankan oleh para pihak pencari keadilan. Peradilan Agama menjadi bagian dari Pengadilan Negara yang mandiri.

\section{e. Masa Pemerintahan Reformasi Pembangunan}

Selama pemerintahan Orde Baru, pembinaan dan pengawasan Peradilan Agama sebagai salah satu pelaksana Kekuasaan Kehakiman, sebagaimana lembaga peradilan lainnya, dilakukan oleh dua lembaga: Yudikatif dan Eksekutif. Pembinaan itu dilakukan oleh Mahkamah Agung, sedangkan pembinaan organisasi, administrasi, dan keuangan badan itu oleh Departemen Agama, berdasarkan Pasal 10 dan Pasal 11 ayat (1) Undang-Undang No. 14 Tahun 1970 tentang Ketentuan-Ketentuan Pokok Kekuasaan Kehakiman jo Pasal 5 Undang-Undang No. 7 Tahun 1989 tentang Peradilan Agama, di mana sekarang sudah diubah dengan Pasal 13 ayat (1) Undang-Undang No. 4 Tahun 2004.

Di masa pemerintahan Reformasi Pembangunan sekarang ini, pembinaan dan pengawasan yang dilakukan Yudikatif dan Eksekutif tersebut sudah dianggap tidak layak lagi, karena jelas mempengaruhi kemandirian Badan Peradilan Agama. Maka harus diadakan perubahan agar Eksekutif tidak mencampuri Yudikatif dan pada tanggal 30 Juli 1999 disahkan UndangUndang No. 35 Tahun 1999 tentang Perubahan atas Undang-Undang No. 14 Tahun 1970 tentang Ketentuan-Ketentuan Pokok Kekuasaan Kehakiman. Sekarang undang-undang tersebut telah diubah menjadi Undang-Undang No. 4 Tahun 2004 tentang Kekuasaan Kehakiman.

Pasal 13 ayat (1) Undang-Undang Nomor 4 Tahun 2004 tentang Kekuasaan Kehakiman berbunyi: Organisasi, administrasi, dan finansial Mahkamah Agung dan badan peradilan yang berada di bawahnya, berada di bawah kekuasaan Mahkamah Agung.

Disahkannya undang-undang tersebut menjadi peristiwa yang amat bersejarah bagi Lembaga Kekuasaan Kehakiman, karena menjadi tonggak sejarah bagi terwujudnya kemerdekaan dan kemandirian dari Kekuasaan Kehakiman secara utuh di bawah Mahkamah Agung, setelah sekian lama pembinaan atasnya dilakukan oleh dua lembaga kekuasaan: Eksekutif 
(Departemen yang bersangkutan) dan Yudikatif (Mahkamah Agung).

Tujuan pemisahan kekuasaan antara Eksekutif dan Yudikatif yang dikehendaki dan diatur oleh Undang-Undang Nomor 4 Tahun 2004 tentang Kekuasaan Kehakiman tersebut adalah memantapkan proses Lembaga Peradilan Agama dalam segi-segi hukum formal dan teknis peradilan, sehingga dapat terwujud Kekuasaan Kehakiman yang merdeka dengan terselenggaranya peradilan yang bebas dari pengaruh dan intervensi kekuasaan Eksekutif dan benar-benar mandiri. Namun, ternyata realisasi kehendak Undang-Undang tersebut bukan hal yang mudah, yang langsung bisa dilaksanakan dengan disahkannya Undang-Undang tersebut.

\section{Filosofis}

Dari sisi filosofis, yang diperhatikan adalah peradilan pada masa Rasulullah saw. dan masa Khulafa ar-Rasyidin. Yang dimaksud dengan Falsafah Hukum Islam adalah setiap qaidah atau aturan yang digunakan untuk mengendalikan masyarakat Islam, baik qaidah itu merupakan ayat al-Qur'an, Hadis, pendapat Sahabat dan Thabi' in, maupun pendapat yang berkembang pada suatu masa dalam kehidupan umat Islam atau pada suatu bidang masyarakat Islam. ${ }^{30}$

Dari Falsafah Hukum Islam itulah kita dapat mengungkapkan ruh syariat yang dibawa al-Qur'an atau yang diilhamkan ke dalam jiwa para ahli al-Qur'an, baik mereka hakim maupun mufti. Singkat kata, Falsafah Hukum Islam adalah sendi-sendi hukum, prinsip-prinsip hukum (sumbersumber hukum), kaidah-kaidah hukum, yang di atasnyalah dibina Undang-Undang Islam. ${ }^{31}$

Setelah tiga belas tahun Rasulullah saw. menegakkan agama Islam dalam masyarakat Arab di Mekah, Rasulullah saw. dengan kehendak Allah berhijrah ke Madinah untuk meneruskan dakwahnya.

Di Madinah, dalam usaha dakwahnya, selain bertugas menyeru dan menyampaikan ajaran-ajaran Allah Swt kepada umat manusia, beliau juga ditugaskan memutuskan hukum dan menyelesaikan berbagai persengketaan yang terjadi di tengah anggota masyarakat. ${ }^{32}$ Beliau diperintahkan untuk memimpin umat beliau pada waktu itu dalam

\footnotetext{
${ }^{30}$ Hasbi Ash-Shiddieqy, Falsafah Hukum Islam, Jakarta: Bulan Bintang, 1975, hlm. 36.

${ }^{31}$ Ibid, hlm. 37.
} 
mengendalikan pengadilan dan memutuskan perkara. Untuk mengetahui bagaimana Nabi Muhammad saw. memutuskan perkara, perhatikanlah maksud hadis yang diriwayatkan Imam Ahmad dalam Musnadnya dari Ummu Salamah ra., isteri Nabi, dia berkata:

Pada suatu hari, datanglah ke rumah Nabi s.a.w dua orang lelaki yang mempertengkarkan soal pusaka yang telah lama terbelengkalai, tidak mempunyai keterangan yang nyata lagi. Maka Rasul s.a.w berkata kepada mereka: "Sesungguhnya kamu datang mengadukan perkaramu kepada Rasulullah, sedang saya ini seorang manusia. Boleh jadi sebahagian kamu lebih pandai menguraikan hujjahnya dari orang lain. Hanyasanya aku ini memutuskan perkara menurut apa yang aku dengar dari keteranganketerangan yang kamu berikan. Maka barang siapa yang aku benarkan keterangannya dari karena pandainya bumbu keterangan dan aku hukumkan untuknya sesuatu dari hak saudaranya, berartilah aku telah memberikan kepadanya sepotong api neraka. Dia akan letakkan yang aku hukumkan kepadanya itu, dilehernya menjadi alat penggerak api di hari kiamat". Setelah Nabi berkata demikian, kedua orang itu pun menangis. Masing-masing mereka mengatakan: segala hakku, aku berikan kepada saudaraku ini. Mendengar itu Nabi s.a.w bersabda: "Pulanglah kamu ke tempatmu dan berbagilah harta itu sama adil antara kamu, kemudian setelah kamu bagi sama banyaknya, berundinglah kamu serta hendaklah kamu masing-masing halal menghalalkan. ${ }^{33}$

Pada masa dunia Islam mulai meluas, di mana sudah banyak kota Islam menghajatkan adanya majelis-majelis peradilan, barulah Rasulullah s.a.w. mengutus beberapa wali negeri (Gubernur) ke daerah-daerah itu.

Pada masa Nabi s.a.w. masih hidup, para wali negeri itu bertindak sebagai pemangku urusan umum rakyat dan bertindak pula sebagai qadli (dalam istilah sekarang, hakim) dalam wilayahnya. Wali-wali itu berkuasa memutuskan segala perkara. Nabi mengangkat Muadz, menjadi gubernur di Negeri Yaman dan Attab bin Asaad menjadi gubernur di negeri Mekah. Segala perkara yang mereka putuskan terus berlaku, tidak perlu meminta atau menunggu pengesahan dari Nabi s.a.w. Demikian keadaan hakim di masa Nabi dan demikian pula di zaman Abu Bakar as-Shidiq.

Di Madinah, Abu Bakar sendirilah yang memimpin pengadilan dan

${ }^{32}$ Hasbi Ash-Shiddieqy, Sejarah Peradilan Islam, Jakarta: Bulan Bintang, 1970, hlm. 12.

${ }^{33} \mathrm{Ibid}, \mathrm{hlm} .13-14$. 
bertindak selaku hakim, sedangkan di berbagai kota Islam lain yang jauh dari Madinah, pengadilan negeri dikendalikan oleh wali-wali negeri (para gubernur) yang diangkat untuk mengurus hukum di daerah-daerah itu.

Kepala negara pada masa Abu Bakar bertindak sebagai orang yang menetapkan hakim (musyarri'), sebagai orang yang memutuskan perkara (qadli/hakim), dan sebagai orang yang melaksanakan putusan.

Lembaga peradilan (qadla') pada masa Nabi saw. dan Abu Bakar ra. dipegang oleh pemangku wilayah amanah (penguasa), belum diadakan pejabat yang secara khusus mengurusi berbagai aturan dalam memutuskan perkara yang dipersengketaan di tengah umat. Yaitu, belum diangkat qadli disamping kepala wilayah, kepala kehakiman yang berdiri sendiri. Barulah pada masa Khulafa ar-Rasyidin, Bani Umayah dan permulaan Bani Abbas, pemisahan qadla' (Lembaga Peradilan) dari tangan gubernur dilakukan. Rasulullah saw. dan Abu Bakar as-Shidiq telah memutus berbagai perkara yang dipersengketakan di tengah-tengah umat, melaksanakan putusan, dan mengangkat hakim secara mandiri.

\section{Yuridis}

Secara yuridis, alasan mengapa Peradilan Agama dimasukkan ke dalam lingkungan peradilan di Indonesia adalah bahwa Negara Republik Indonesia, sebagai negara hukum yang berdasarkan Pancasila dan Undang-Undang Dasar 1945, bertujuan mewujudkan tata kehidupan bangsa yang sejahtera, aman, tenteram, dan tertib. ${ }^{34}$ Pasal 27 ayat (1) Undang-Undang Dasar 1945 menyatakan: Segala warga Negara bersamaan kedudukannya di dalam hukum dan Pemerintahan dan wajib menjunjung Hukum dan Pemerintahan itu dengan tidak ada kecualinya.

Sedangkan Pasal 29 ayat (1) dan (3) Undang-Undang Dasar 1945 juga menyatakan:

(1) Negara berdasar atas Ke-Tuhanan Yang Maha Esa

(2) Negara menjamin kemerdekaan tiap-tiap penduduk untuk memeluk agamanya masing-masing dan untuk beribadat menurut agamanya dan kepercayaannya itu.

Maka, untuk mewujudkan tata kehidupan seperti itu dan untuk menjamin kesederajatan kedudukan warga negara di dalam hukum diperlukan upaya menegakkan keadilan, kebenaran, ketertiban, dan kepastian

\footnotetext{
${ }^{34}$ Baca, “Undang-Undang No. 7 Tahun 1989 tentang Peradilan Agama".
} 
hukum yang mampu memberikan pengayoman atas warga masyarakat. Dan salah satu upaya menegakkan keadilan, kebenaran, ketertiban, dan kepastian hukum tersebut adalah melalui Pengadilan Agama.

Dalam Undang-Undang Dasar 1945, satu-satunya pasal yang jelas berbicara tentang kekuasaan kehakiman adalah Pasal 24. Dari Pasal 24 ini, kita dapat mengambil kesimpulan bahwa pelaksana kekuasaan kehakiman adalah sebuah Mahkamah Agung dan lain-lain badan kehakiman menurut Undang-Undang, yang berarti bahwa lain-lain badan kehakiman ini harus disesuaikan dengan kebutuhan hukum dan kesadaran hukum masyarakat. ${ }^{35}$

Undang-Undang Organik yang menjabarkan Pasal 24 UndangUndang Dasar 1945 tersebut adalah Undang-Undang No. 14 Tahun 1970 jo Undang-Undang No. 35 Tahun 1999 tentang Perubahan Atas UndangUndang No. 14 Tahun 1970 tentang Ketentuan-ketentuan Pokok Kekuasaan Kehakiman, yang kemudian diubah dengan Undang-Undang No. 4 Tahun 2004, yang menentukan adanya 4 lingkungan Peradilan, yaitu Peradilan Umum, Peradilan Agama, Peradilan Militer, dan Peradilan Tata Usaha Negara.

\section{Sosiologis}

Selain historis, filosofis, yuridis, faktor lainnya yang menunjukkan mengapa Peradilan Agama tetap dapat bertahan di Indonesia adalah faktor sosiologis.

Faktor ini terkait dengan apa yang telah diuraikan di muka, bahwa keberadaan Peradilan Agama di Indonesia sudah memakan waktu panjang, sepanjang keberadaan agama Islam itu sendiri di negara ini, karena Islam merupakan agama hukum. Dalam konteks ini, pernyataan itu berarti bahwa disamping mengandung berbagai kaidah yang mengatur hubungan antara manusia dengan Allah yang harus dijalankan oleh para pemeluknya secara pribadi, agama Islam juga mengatur hubungan antara manusia dengan manusia yang lain dalam kehidupan masyarakat yang memerlukan bantuan penyelenggara negara untuk dapat dilaksanakan dengan sempurna.

Ini nampak dalam peristiwa disetujuinya Rencana Undang-Undang

${ }^{35}$ Busthanul Arifin, "Peradilan Agama di Indonesia", (ed), Mimbar Hukum, No. 10 Thn. IV, 1993, hlm. 1. 
Peradilan Agama oleh DPR RI pada tanggal 14 Desember 1989, yang pada akhirnya disahkan menjadi Undang-Undang Nomor 7 Tahun 1989 tentang Peradilan Agama pada tanggal 29 Desember 1989. Lahirnya UndangUndang tersebut selain merupakan peristiwa hukum dan peristiwa politik juga sangat erat kaitannya dengan keyakinan umat Islam. ${ }^{36}$

Lembaga Peradilan Agama sudah tumbuh dan berkembang sesuai dengan keyakinan umat Islam jauh sebelum Balanda menjajah Indonesia. Usaha Belanda menghapuskan lembaga itu tidak berhasil dan karenanya wajar apabila umat Islam sangat mendambakan segera keluarnya Undang-Undang Peradilan Agama sejak Indonesia memperoleh kemerdekaan. Tak diberlakukannya Undang-Undang No. 19 Tahun 1948, yang memasukkan peradilan agama ke dalam peradilan umum, dapat dikatakan sebagai salah satu gambaran bahwa bangsa Indonesia sesungguhnya menghendaki suatu peradilan agama yang berdiri sendiri dan diatur di dalam Undang-Undang sesuai dengan kehendak dari Pasal 24 Undang-Undang Dasar 1945. Maka, keluarnya Undang-Undang Darurat No. 1 Tahun 1951 yang menghapus lembaga peradilan adat dan swapraja, tetapi mempertahankan keberadaan peradilan agama di Indonesia, dapat dianggap sebagai bukti bahwa secara sosiologis bangsa Indonesia tetap mempertahankan Peradilan Agama.

Persoalan hukum yang menarik untuk diteliti adalah kemandirian Peradilan Agama dalam konteks pelaksanaan Pasal 49 dan 50 UndangUndang No. 7 Tahun 1989 jo Undang-Undang No. 3 Tahun 2006. Sebagai salah satu pelaksana kekuasaan kehakiman bagi rakyat pencari keadilan yang beragama Islam, yang terkait dengan perkara tertentu yang diatur di dalam Undang-Undang ini, ${ }^{37}$ seharusnya keberadaan dan kemandirian dari Peradilan Agama telah terwujud, ${ }^{38}$ namun dalam kenyataan masih terjadi disturbance dan keragaman pandangan hukum yang berlaku di Indonesia. Di antaranya adalah sebagai berikut:

1. Pasal 49 Undang-Undang No. 3 tahun 2006 tentang Perubahan atas Undang-Undang No. 7 Tahun 1989 tentang Peradilan Agama menyatakan :

Pengadilan Agama bertugas dan berwenang memeriksa, memutus,

\footnotetext{
${ }^{36}$ Muchtar Zarkasyi, “Kerangka Historis Pembentukan Undang-Undang No. 7 Tahun 1989", (ed), Mimbar Hukum, No. 1 Thn. I, 1990, hlm. 1.

${ }^{37}$ Muhammad Daud Ali, Asas-Asas Hukum Islam, Jakarta: Rajawali, 1991, hlm. 251.

38 Ahmad Roestandi, "Beberapa Catatan Signifikan di Sekitar Pelaksanaan Undang-Undang Peradilan Agama", Mimbar Hukum, No. 18 Thn. VI, 1995, hlm. 82.
} 
dan menyelesaikan perkara di tingkat pertama antara orang-orang yang beragama Islam di bidang : a. perkawinan, b. waris, c. wasiat, d. hibah, e. wakaf, f. zakat, g. infaq, h. shadaqah, dan i. ekonomi syari'ah.

Dalam Penjelasan Undang-Undang No. 3 Tahun 2006 tentang Perubahan atas Undang-Undang No. 7 Tahun 1989 tentang Peradilan Agama, huruf b menyatakan :

Yang dimaksud dengan "waris" adalah penentuan siapa yang menjadi ahli waris, penentuan mengenai harta peninggalan, penentuan bagian masing-masing ahli waris, dan pelaksanaan pembagian harta peninggalan tersebut, serta penetapan pengadilan atas permohonan seseorang tentang penentuan siapa yang menjadi ahli waris, penentuan pembagian masing-masing ahli waris.

Dari pernyataan itu, maka timbul gangguan apabila tidak semua ahli waris beragama Islam atau beda agama. Hal tersebut karena Pasal 173 Kompilasi Hukum Islam (KHI) menyatakan :

"Seseorang terhalang menjadi ahli waris apabila dengan putusan Hakim yang telah mempunyai kekuatan hukum yang tetap dihukum karena :

a. dipersalahkan telah membunuh atau mencoba membunuh atau menganiaya berat pada pewaris.

b. dipersalahkan secara memfitnah telah mengajukan pengaduan bahwa pewaris telah melakukan suatu kejahatan yang diancam dengan hukuman 5 tahun penjara atau hukuman yang lebih berat.

2. Pasal 50 Undang-Undang No. 7 Tahun 1989 jo Pasal 50 ayat (1) Undang-Undang No. 3 Tahun 2006 menyatakan: Dalam hal terjadi sengketa hak milik atau keperdataan yang lain dalam perkara-perkara sebagaimana yang dimaksud dalam Pasal 49, maka khusus mengenai obyek yang menjadi sengketa tersebut harus diputus lebih dahulu oleh Pengadilan dalam lingkungan Peradilan Umum.

3. Pasal 54 Undang-Undang No. 7 Tahun 1989 jo Undang-Undang No. 3 Tahun 2006: Hukum Acara yang berlaku pada Pengadilan dalam lingkungan Peradilan Agama adalah Hukum Acara Perdata yang berlaku pada Pengadilan dalam lingkungan Peradilan Umum, kecuali yang telah diatur secara khusus dalam Undang-Undang ini: Sistem pemanggilan dalam $\mathrm{HIR} / \mathrm{Rbg}$, dalam perceraian yang terlalu lama, demikian juga sistem pembuktian dalam perkara zina yang tidak tepat.

4. Ketentuan-ketentuan hukum perkawinan yang diatur di dalam Islam 
belum terjabar secara menyeluruh. ${ }^{39}$ Isbat nikah belum diatur, syarat dan rukun perkawinan belum dirumuskan. Larangan kawin belum menyeluruh. Kawin hamil tidak dibicarakan. Kedudukan dan porsi harta bersama masih belum pasti. Masalah iddah belum terinci.

Dari kenyataan, pengamatan, dan pengalaman di lapangan yang dikemukakan di atas, dapat dikatakan bahwa keberadaan dan kehidupan Peradilan Agama di Indonesia belum mandiri sebagai badan peradilan atau badan kekuasaan kehakiman. Sarana hukum sebagai rujukan yang menjadi penopang kehidupan dan keberadaannya belum sempurna.

Fakta bahwa ketidakmandirian Peradilan Agama tersebut ternyata disebabkan oleh kondisi internal Undang-Undang benar-benar merupakan satu persoalan yang sangat menarik untuk diteliti. Selain telah mendorong minat akademik peneliti, penelitian atas fakta tersebut juga sangat besar manfaatnya terutama bila hasilnya dapat memberikan kontribusi besar bagi kebijakan ke depan dan kontribusi hukum Islam terhadap hukum nasional.

\section{Penutup}

Dari kajian di atas dapat disimpulkam bahwa upaya untuk mengembalikan kemandirian Peradilan Agama adalah dengan langkahlangkah sebagai berikut:

1. Mengadakan sosialisasi menjadikan masyarakat sadar hukum, dalam arti memahami ketentuan-ketentuan yang terkandung dalam UndangUndang No. 7 Tahun 1989 tentang Peradilan Agama jo UndangUndang No. 3 tahun 2006 tentang Perubahan atas Undang-Undang No. 7 Tahun 1989 tentang Peradilan Agama, Kompilasi Hukum Islam dan peraturan-peraturan lain yang terkait.

2. Membina dan meningkatkan kesadaran hukum masyarakat sehingga warga taat hukum dan secara sukarela tanpa paksaan dan dorongan dari siapa pun melaksanakan hak dan kewajibannya sebagaimana ditentukan Undang-Undang No. 7 Tahun 1989 tentang Peradilan Agama jo Undang-Undang No. 3 Tahun 2006 Kompilasi Hukum Islam dan peraturan-peraturan lain yang terkait.

3. Menggunakan teori kerukunan dan musyawarah sesuai prinsip negara Nomokrasi Islam dan Negara Pancasila.

${ }^{39}$ Yahya Harahap, Kedudukan Kewenangan dan Acara Peradilan Agama UndangUndang No. 7 Tahun 1989, Jakarta: Sinar Grafika, 2003, hlm. 24. 
4. Menggunakan teori Al-Maslahah, karena melalui prinsip ini semua aspek kemasyarakatan yang belum diatur dalam al-Qur'an dan Sunnah Rasul dapat ditata sendiri oleh manusia atau prinsip-prinsip dasar yang bersifat umum yang ada dalam al-Qur'an bisa dirinci lebih lanjut guna menentukan bentuk aplikasinya dalam kehidupan masyarakat dan negara sepanjang tak bertentangan dengan jiwa hukum Islam (Syari'ah).

\section{Daftar Pustaka}

Ahmad Roestandi, “Beberapa Catatan Signifikan di Sekitar Pelaksanaan Undang-Undang Peradilan Agama", Mimbar Hukum, No. 18 Thn. VI, 1995

Ahmad Rofiq, Hukum Islam di Indonesia, Ctk 4, Jakarta: PT. Raja Grafindo Persada, 2000

Busthanul Arifin, "Peradilan Agama di Indonesia", (ed), Mimbar Hukum, No. 10 Thn. IV, 1993Daud Ali, "Undang-Undang Peradilan Agama”, Panji Masyarakat, (ed.), No. 634 tanggal 1-10 Januari, 1990, Jakarta

Departemen Agama RI, “Laporan Bagian Proyek Penelitian Yurisprudensi Peradilan Agama", Proyek Peningkatan Penelitian/Survey Keagamaan, Jakarta, 1971/1972

Departemen Agama, "Yurisprudensi Badan Peradilan Agama", Ditbinbapera Islam, Jakarta, 1977

Hasbi Ash-Shiddieqy, Falsafah Hukum Islam, Jakarta: Bulan Bintang, 1975. Sejarah Peradilan Islam, Jakarta: Bulan Bintang, 1970.

Hamka, Sejarah Umat Islam, Jilid III, Jakarta: Bulan Bintang, 1981.

Idrus Ramulyo M, Beberapa Masalah tentang Hukum Acara Perdata Peradilan Agama dan Hukum Perkawinan Islam, Jakarta: Ind-Hell Co, 1985.

Mahadi, "Peranan Pengadilan Agama di Indonesia”, Kertas Kerja, Laporan Hasil Simposium Sejarah Peradilan Agama, Bagian Proyek Pembinaan Administrasi Hukum dan Peradilan Agama, Jakarta, 1982/1983.

Marulah Pardede, Eksistensi dan Kedudukan Hukum Peradilan Agama dalam Tata Hukum Indonesia, Jakarta: Angkatan Bersenjata, 24 Agustus 1989.

Muchtar Zarkasyi, "Kerangka Historis Pembentukan Undang-Undang No. 7 Tahun 1989", (ed), Mimbar Hukum, No. 1 Thn. I, 19901.

Munawir Sjadzali, Landasan Pemikiran Politik Hukum Islam dalam Rangka Menentukan Peradilan Agama, dalam Tjun Suryaman (ed), tanpa nama. 
Munawir Sjadzali, Peradilan Agama dan Kompilasi Hukum Islam, dalam Moh. Mahfud dkk, (ed), Peradilan Agama dan Kompalasi Hukum Islam dalam Tata Hukum di Indonesia, UII Press, Yogyakarta, 1993 Muhammad Daud Ali, Asas-Asas Hukum Islam, Jakarta: Rajawali, 1991. "Sejarah Peradilan Agama", Serial Media Dakwah, ASA, Jakarta, Agustus, 1989.

Yahya Harahap, Kedudukan Kewenangan dan Acara Peradilan Agama Undang-Undang No. 7 Tahun 1989, Jakarta: Sinar Grafika, 2003.

Zaini Ahmad Noeh dan Abdul Basit Adnan, Sejarah Singkat Pengadilan Agama Islam di Indonesia, Bina Ilmu: Surabaya, 1983.

Taufiq Hamami, "Ikhtisar sejarah Peradilan agama di Indonesia", (ed) Mimbar Hukum. No. 59 Th.XIV, 2003.

"Penjelasan Atas Undang-Undang Republik Indonesia Nomor 7 Tahun 1989 tentang Peradilan Agama".

Victor Tanja, Forum RUUPA, Editor, No. 48/Th II, Jakarta, 5 Agustus 1989.

Sayuti Thalib, Receptio a Contrario, Jakarta: Pura Aksara, 1982.

"Undang-Undang No. 7 Tahun 1989 tentang Peradilan Agama".

Laporan Bagian Proyek Penelitian Yurisprudensi Peradilan Agama.

Laporan Bagian Proyek Penelitian Yurisprudensi Peradilan Agama. 